\title{
Nexus between FDI, Infrastructure Investment, Tourism Revenues, and Economic Growth: Mega Event Evidence
}

\author{
Mustafa Mohammad Alalawneh ${ }^{1 *}$, Jeyhun Mammadov ${ }^{2}$, Ameen Alqasem ${ }^{3}$ \\ ${ }^{1}$ PhD Student, Department of Economic and Managment, Khazar University, Baku, Azerbaijan \\ ${ }^{2}$ Associate Professor, Department of Economic and Management, Khazar University, Baku, Azerbaijan \\ ${ }^{3}$ Jordanian Researcher, Department of Economic, Yarmouk University, Irbid, Jordan
}

\begin{abstract}
The object of this study is to examine the response of economic growth in Germany to 2006 FIFA World Cup hosting (represented by the heavily influenced variables of this huge event: Growth of Infrastructure Spending, Tourism Revenues, and Foreign Direct investment) during the period (2000 - 2017). The study employed Dynamic Ordinary Least Square (DOLS) approach to estimate the long-run equilibrium relationships amongst the variables. The results indicate that there is a cointegrating long-run relationship among the studied variables and provide empirical evidence showing that an increase in the growth of infrastructure spending (GINFR) 1 unit leads to an increase in the growth of GDP (GGDP) by 0.374 unit, an increase in the tourism revenues (TR) 1 unit leads to increase in the growth of GDP (GGDP) by 0.155 unit, and an increase in foreign direct investment (FDI) 1 unit leads to an increase in the growth of GDP (GGDP) by 0.055 unit. What distinguishes this paper is that it is one of the rare studies that went beyond the short effect of megaevents on the host country and investigated the long-term economic impact of the most important macro variables associated with mega-events on economic growth.
\end{abstract}

\section{Keywords:}

World Cup Hosting;

Economic Growth;

Infrastructure Spending;

Tourism Revenues;

Foreign Direct Investment; Germany.

\section{Article History:}

Received: 05 June 2021

Revised: 28 September 2021

Accepted: 12 October 2021

Published: $01 \quad$ December 2021

\section{1- Introduction}

With the spread of capitalism and its dominance over the global economy, sports in general and football, in particular, have been associated with many of the consumer values of modern societies to become part of the economic cycle. It is fertile ground for advertising and propaganda. It is a haven for advertisers because of its popularity, proliferation, ability to market products and create new consumption patterns. In the modern era, football has enjoyed a new style of soft power that will affect the public and make it adopt the lifestyles such as those promoted by a football player, which is well done by advertising companies to exploit it for its benefit [1].

It has become important to understand the nature of the relationship between economics and sports and to understand the mutual impact that one can have on the other. Sport has become an active and stimulating part of the economy, and the economy has become dependent on sport as a tool for creating value-added and generating profits. This also explains the race of countries to embrace global sports competitions, although it is required to increase government spending directed to the establishment and maintenance of infrastructure and provide the necessary equipment to receive the sporting event, the issue here is a long-term investment for countries, and many studies suggest that host countries expect revenues to exceed the amount of spending, which drives them to apply for the

*CONTACT: alalawnehmustafa@gmail.com

DOI: http://dx.doi.org/10.28991/esj-2021-01323

(C) 2021 by the authors. Licensee ESJ, Italy. This is an open access article under the terms and conditions of the Creative Commons Attribution (CC-BY) license (https://creativecommons.org/licenses/by/4.0/). 
organization of global sports competitions on their territory [2]. For example, according to a study by the FIFA World Cup Organizing Committee, the 2018 World Cup is expected to boost Russia's economic growth by about $\$ 3$ billion a year over the next five years, in addition, the event represents a good opportunity for Russian companies that have implemented infrastructure projects to highlight their efficiency and thus export foreign direct investment abroad [3].

Hosting major events, most notably the FIFA World Cup, is a dream and ambition for developing and developed countries, especially those that aspire to be one of the major centers and landmarks in the world. Hosting these events is a catalyst for rapid urbanization for countries because of their positive economic, political or state image abroad. Mega event hosting of the State is seen internationally as evidence of the State's accession to the list of first-class States [4].

Mega- events are global non-traditional events of great importance to policymakers, management, and society of the host country. British sociologist Maurice Roche defined huge events as "short-term events with long-term effects on host cities. The major events are accompanied by comprehensive infrastructure development, efficiency requirements in hosting of large numbers of participants, and in the case of The success of the State, the mega-events create a new identity for the host country and a positive (often constant) mental image through intense focus on the country in the international and domestic media by all means, with long-term benefits especially tourism, infrastructure rehabilitation and attracting of foreign investments [1].

This study examines the impact of hosting the FIFA World Cup on economic growth of the host country, specifically the impact of hosting the World Cup 2006 in Germany. The study period will be from 2000 to 2017. Thus, the study covered the period of preparation for the World Event in addition to the period of hosting and beyond, which allows us to find the economic impact in the long term. Through the economic and sports literature and previous studies, the most important economic variables affected and heavily influenced by the hosting of the World Cup are foreign direct investment, tourism revenues and infrastructure spending. They will serve as independent and representative variables of hosting the FIFA World Cup having an impact on economic growth in Germany.

This paper investigated the effect of hosting the World Cup on economic growth and also is one of the rare studies that used macroeconomic indicators as representative variables of the hosting event. The importance of this study is that it not only uses the descriptive approach but also the standard statistical approach (Dynamic Ordinary Least Square, DOLS) to demonstrate the long-term economic impact.

\section{2- Literature Review}

Economists have recently noted the impact of hosting mega-events, especially sports, on the economies of the host countries, and some studies have focused on the long-term impact on some macroeconomic variables such as urban growth, tourism revenues, foreign investment, and economic growth. The most important of these studies are: Study of Hermann et al. (2012) [5] aimed to investigate the economic impact of hosting the 2010 World Cup, specifically the impact on the years following the year of the event. The study targeted the population in nine areas around the municipality of Tsh-wane, with a number of 1135 participants, where a questionnaire was designed and using modern statistical methods, the questionnaire was analyzed and the results reached the local residents' sense of positive effects after a year of hosting, although most of the residents did not attend the championship matches. This study is an incentive for decision-makers and tournament organizers to enhance the sustainability of mega sporting events in the future.

Liu (2013) compared the economic impact of hosting the FIFA World Cup in the short and long term. The paper used a qualitative approach and focused on 3 main axes in hosting the World Cup, which are the development of infrastructure through modernization of transportation, the establishment of new stadiums and sports centers, a sense of satisfaction, and the improvement of the image of the host country internationally. In the future, the study recommended relying on a quantitative approach to measure the impact of hosting major events on macroeconomic indicators, because the quantitative approach has the ability to accurately measure the effects. Li (2013) [7] focused on the economic impact of spending on infrastructure for the purpose of hosting major sporting events and investigated the impact of hosting the 2008 Beijing Olympics on economic growth. The study used CGE models to achieve its goals, and the results showed the long-term positive economic impact.

What distinguishes the paper of Lee et al. (2017) is its interest in investigating the impact of hosting mega-events on the host region and its neighboring regions, and used the input and output model to analyze the study data. The study targeted the Expo 2012 Yeosu Korea (BIE International Expo), and the study showed the spending rate of Yeosu visitors in the host region and neighboring regions and the impact of these expenditures on production and income. The study also clarified the impact of the added value of hosting the exhibition and the number of jobs created by the exhibition. The results of the study indicated that $80 \%$ of the effects were caused by the host region and $20 \%$ were affected by the neighboring regions. The study recommended taking into account the economic effects of hosting mega-events on the neighboring regions in addition to the host region. 
Tabi et al. (2018) [9] investigated the impact of small and micro-enterprises associated with hosting mega-events such as the Olympic Games on economic development in host countries. The sample of the study consisted of 155 participants from 5 continents. A questionnaire was designed that contains questions about economic development, infrastructure development, environment, and lifestyles. The results of the study, after analyzing the collected data, showed the tangible positive impact of small projects on economic development and the prominent role of hosting major sporting events in developing the infrastructure of the host cities. The study of Sumarsono et al. (2018) [10] aimed to analyze the impact of major tourism events on economic growth in the city of Surakarta. The study relied on the descriptive approach through data collection and analysis, and the study showed that the organization of a huge tourist event in the city is affected by spending on infrastructure, security, and safety. The results showed that the organization of mega tourist events positively affects the economic growth in the city.

According to Wan and Song (2019) [11] study compared the impact of hosting the Olympic Games in London and hosting the FIFA World Cup in Brazil on economic growth in the two countries. The study adopted a panel data approach and using cross-sectional correlations between the two countries. The paper showed that the impact of hosting mega-events differs between developed and developing countries, especially in the long run, and that the most important macro variables associated with hosting mega-events and affecting economic stimulus are the cost of investment in infrastructure and the cost of media promotion. The findings showed that the positive effect is more pronounced in the United Kingdom than in Brazil. With regard to the Oshimi (2020) [12] study, it was concerned with verifying the validity and reliability of scale of social impact for the Tokyo Olympic and Paralympics Games 2020. To achieve the aim of the study, a survey of Tokyo and neighboring cities was conducted, and a scale consisting of 10 factors and 32 items was designed. The results of the study showed the difficulty of measuring the social impact of the Olympic Games in Japan, due to a partial deficiency in the standards of the scale.

The study of Wolfe et al. (2021) [13] illustrates the role and importance of mega-events, particularly the Olympic Games, the FIFA World Cup, and the Commonwealth Games, in spreading urban space and their positive impact on the urban development of the cities hosting these sporting events, as well as their impact on politics, trade, and culture. What distinguishes this study is that it provides modern and innovative ways to understand the effect of mega-events on individuals, communities, and host cities. Finally, the study of Do et al. (2021) [14], which attempted to understand the impact of mega sporting events on urban growth and economic development in host cities, targeting the 2018 Pyeongchang Winter Olympic Games using the urbanization index and land cover ratio through Sentinel-2 satellite images. The results of the study showed a positive impact of mega-events on urban growth in the city, and that one of the most important economic indicators that responded to the mega-event was tax revenues and land prices.

Most of the previous studies dealt with the impact of many mega sporting events on the host cities and countries, and some studies focused on the direct economic impact such as the impact of hosting the mega-events on economic growth, and others on the indirect economic impact such as urbanization, in addition to some studies dealing with the social impact. There are also studies that have compared the impact of huge sporting events on developed and developing countries. Most of the previous studies adopted the descriptive approach for data collection and analysis. What distinguishes this study is its reliance on a relatively long period of time representing the preparation period for hosting, the hosting period, and the post-hosting period, and its use of representative macroeconomic variables for hosting major events such as foreign direct investment, spending on infrastructure and tourism revenues. This study also used modern standard statistical methodology along with descriptive analysis to investigate the impact of mega sporting events on economic growth in the long term.

Sports in Germany are an important part of German culture. In 2006, there were 27.5 million people in 91,000 sports clubs in Germany. Most of these sports are recognized by the German Olympic Committee [15]. Germany is one of the most powerful countries in the football world where it won 4 World Cups and 3 European Cups, and the intense competition among countries to host the World Cup seems to reflect the enormous economic and noneconomic benefits of host countries. When Germany was chosen to host the 2006 World Cup on July 6, 2000, the German government launched a series of projects for the huge football festival, spending 1.5 billion Euros to renovate old stadiums and create 12 new stadiums in 12 host cities. It also spent 3.9 billion Euros on roads and railways, with 500 million Euros on a new traffic management system [16]. The figures show that FIFA and Germany spent a lot of money to secure a historic tournament that benefited not only millions of guests and about 15,000 journalists and media professionals, but also Millions of viewers who watched television screens around the world, and the 2006 World Cup was considered one of the most-watched events in history with more than 3 billion people watched 64 matches, ranking fourth in the most-watched tournaments after 1994, 2002 and 1998, which are certainly recorded when the world remembers the 2006 finals [17].

The following table shows the cost of constructing and maintaining stadiums in twelve host cities in Germany, as well as the cost of spending on transport infrastructure in these cities. The table below shows that the main stadium in Munich, Germany, is the highest cost of 340 million Euros, which opened in 2005 and has a capacity of 67.416 thousand spectators $[18,19]$. 
Table 1. Construction Costs and Expenditure on Transport Infrastructure.

\begin{tabular}{cccc}
\hline Host city & $\begin{array}{c}\text { Stadium capacity for the } \\
\text { 2006 FIFA World Cup }\end{array}$ & $\begin{array}{c}\text { Construction costs } \\
\text { (million Euros) }\end{array}$ & $\begin{array}{c}\text { Expenditure on transport } \\
\text { infrastructure (million Euros) }\end{array}$ \\
\hline Berlin & 66001 & 242 & 486 \\
Dortmund & 60285 & 36 & 28 \\
Frankfurt & 43324 & 126 & 53 \\
Gelsenkirchen & 48426 & 186 & 58 \\
Hamburg & 40226 & 105 & 312 \\
Hannover & 39297 & 64 & 123 \\
Kaiserslautern & 41297 & 71 & 90 \\
Cologne & 40590 & 117 & 596 \\
Leipzig & 39898 & 116 & 301 \\
Munich & 67416 & 340 & 30 \\
Nuremberg & 36898 & 56 & 198 \\
Stuttgart & 47757 & 51 & \\
\hline
\end{tabular}

Table 1 shows the cost of hosting the 2006 FIFA World Cup in Germany, which is estimated at 5.5 billion Euros, and according to the statistics and estimates of the German government, this huge event created 50,000 jobs and generated an additional economic value of about 1.5 billion Euros, And an increase in tax revenues for the years 2007 and 2008 by about 600 million Euros, in addition to the German government's estimates of the total value of economic activity resulting from organizing the tournament up to 3 billion Euros [19].

The figure below shows the cost of hosting the World Cup in Germany and some countries; we note that the cost of hosting the World Cup has not been high in the past. In 1994, the United States hosted the World Cup, spending around \$ 340 million at the World Cup, and at the 1998 World Cup in France, the cost was almost \$ 340 million, while the cost of hosting the World Cup 2006 in Germany has reached about \$ 6.2 billion, and in 2022, Qatar will have a date to host the World Cup, where the Qatari government has allocated huge sums of \$200 billion to host the most important event globally [20].

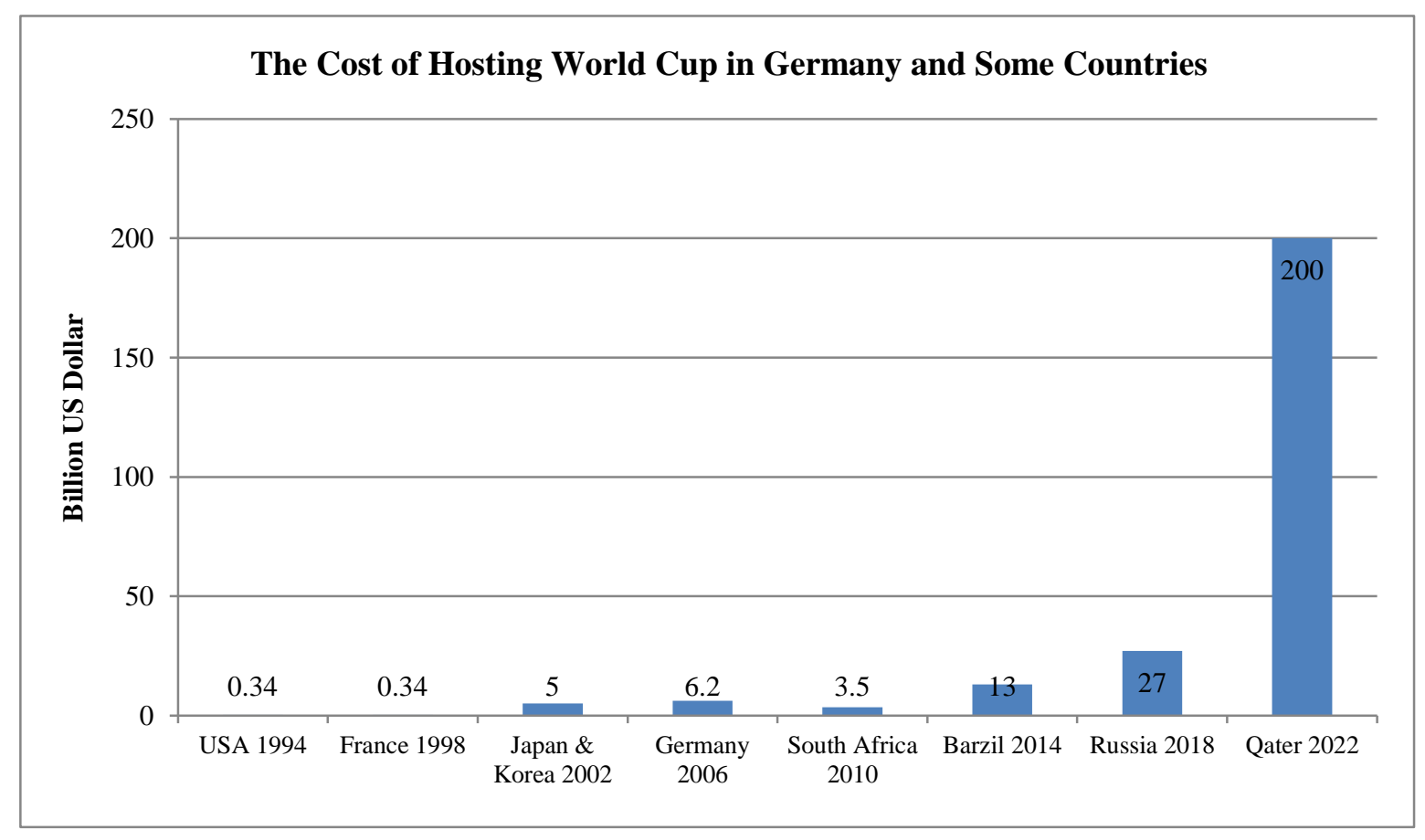

Figure 1. The cost of hosting world cup in Germany and some countries.

Regardless of the high costs of hosting and organizing the World Cup in 2006, the tournament's revenues were very large, reaching nearly \$ 12 billion (Distributed and divided by the host country and FIFA as shown in Figures 2 and 3 ) and a $0.5 \%$ growth in net national income, which helped the German economy to recovery. This sports activity from an economic point of view is one of the main reasons that contributed to the development of the host city and its transformation from a medium-sized city to a large economic center. The expert on sports economics, HolgerPreuss, 
indicates that the city of Munich jumped, because of the establishment of these events, fifteen years to the forward, the infrastructure sector in the city has witnessed rapid development, such as the construction of streets and underground trains. While the country has seen a surge in sales of food and beverages, shirts and other sports equipment, with sales rising to about $\$ 3$ billion. World Cup marketing revenues have also seen an impressive boom in recent years, as revenues between 1998 and 2006 rose from \$ 190 million to \$2,150 million [21].

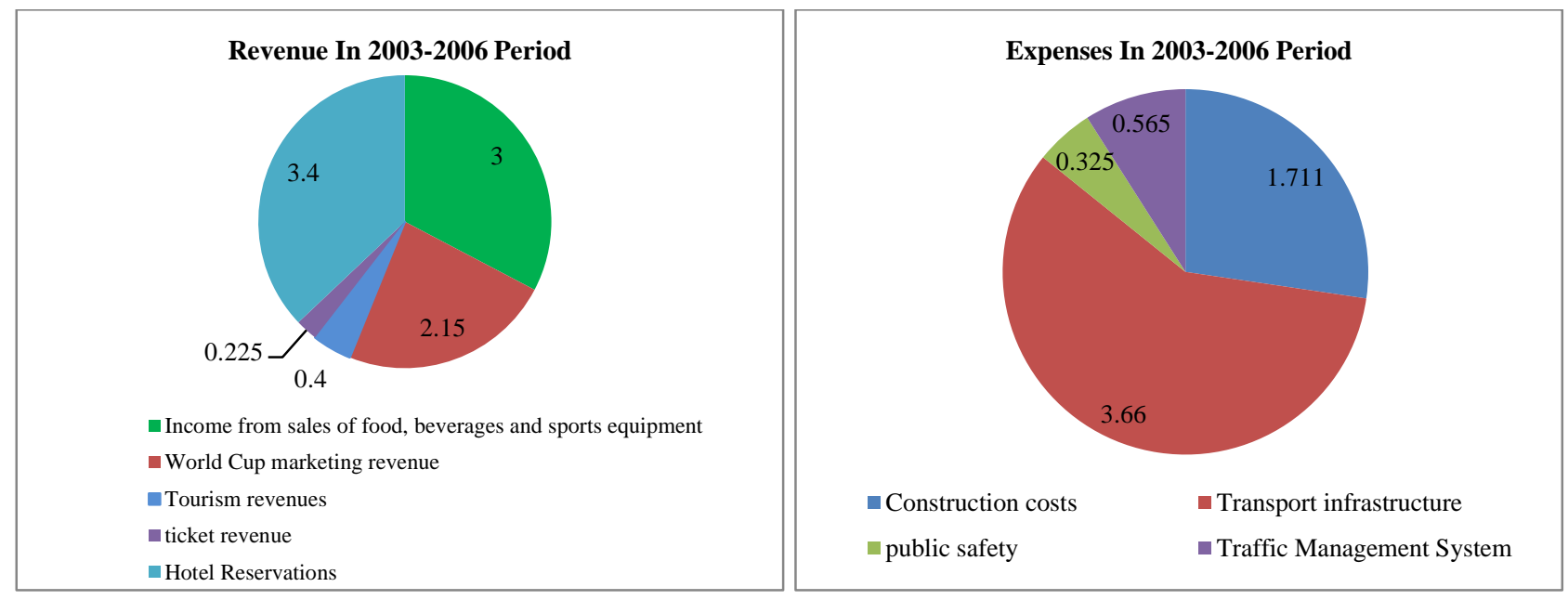

Figure 2. Germany's revenues and expenses to host the World Cup (\$ 1 billion).

The tournament also added about 50,000 new jobs to the German economy. As well as full - service of restaurants and breweries throughout the tournament. The number of fans who visited Germany was about 15 million and higher than expected according to the German government report. Tourism revenues during the World Cup month were around \$ 400 million. The number of ticket holders who came to Germany was estimated at 1.1 million where ticket prices ranged from $\$ 50$ to $\$ 665$, and revenues totalled $\$ 225$ million $[22,23]$.

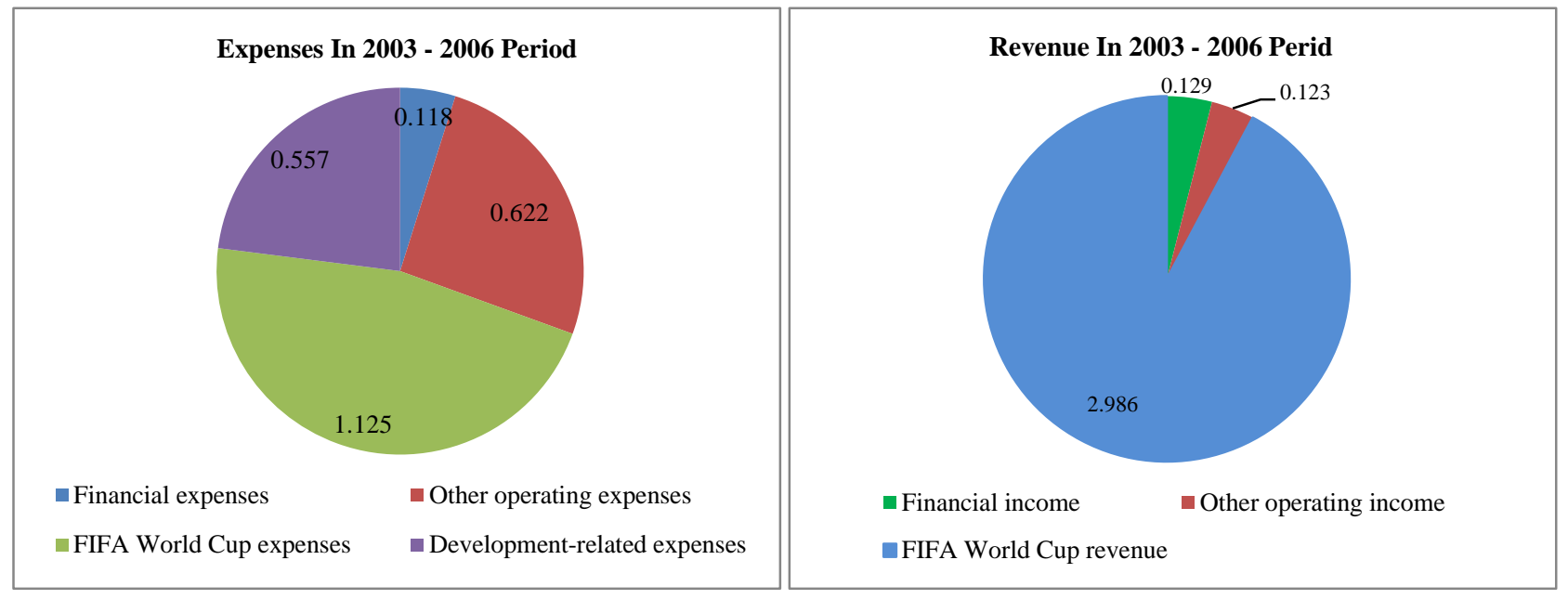

Figure 3. FIFA's revenues and expenses in the 2006 World Cup.

Figures 2 and 3 show that Germany and FIFA's revenues from the tournament were $\$ 9.175$ billion and $\$ 3.288$ billion respectively, and expenditures were \$ 6.261 billion and $\$ 2.422$ billion, respectively.And that the benefit of hosting the World Cup 2006 not only for economic benefit but there was an increase in the birth rate in Germany, where the birth rate in Germany before the World Cup 1.33 children/mother, which is one of the lowest rates in European countries [24]. Nine months after the end of the tournament, the rate of increase in the birth rate rose to $10 \%$, because events during the World Cup have a strong impact on the rate of happiness in individuals and thus increase the birth rate [25].

\section{3- Data and Methodology}

As the study relied on the quantitative approach, the data of the study were extracted from the reports of the German federal government and the statistical data issued by the International Monetary Fund and the World Bank, in addition to the data found in previous studies, books, and scientific references [26, 27]. In this study, descriptive and standard methods were used. The diagnostic tests were carried out to use the appropriate standard model in analyzing 
the semi-annual data during the study period (2000 - 2017). The study used the following variables: expenditure on infrastructure, tourism revenues and foreign direct investment, as representative variables of the economic impact of hosting the World Cup in Germany 2006 on economic growth. These variables were chosen because many previous studies and economic literature showed that these economic variables are the most affected by this huge event [28]. The period 2000 to 2017 was chosen as it represents the period of preparation for the tournament and the period of hosting and the period after the hosting.

The linear economic model was used, and because the study aims to investigate and examine the Co-integration relationship in the long run, and based on the results of the diagnostic tests; the Dynamic Ordinary Least Square (DOLS) was used as a standard analysis tool [29].So the standard model as follows:

$G G D P=f(G I N F R, T R, F D I)$

$G G D P=\beta_{0}+\beta_{1} G I N F R_{t}+\beta_{2} T R_{t}+\beta_{3} F D I_{t}+\mu_{t}$

Where; GGDP: Growth rate of gross domestic product (\%), GINFR: Growth rate of infrastructure spending (\%), TR: Tourism revenues, FDI: Foreign direct investment flows to Germany, $\beta_{0}, \beta_{1}, \beta_{2}, \beta_{3}$ : Parameters of the model, $\mu_{t}$ : Random error, and $t$ : Time period.

To illustrate the econometric methodology used in this study, the following flowchart shows this:

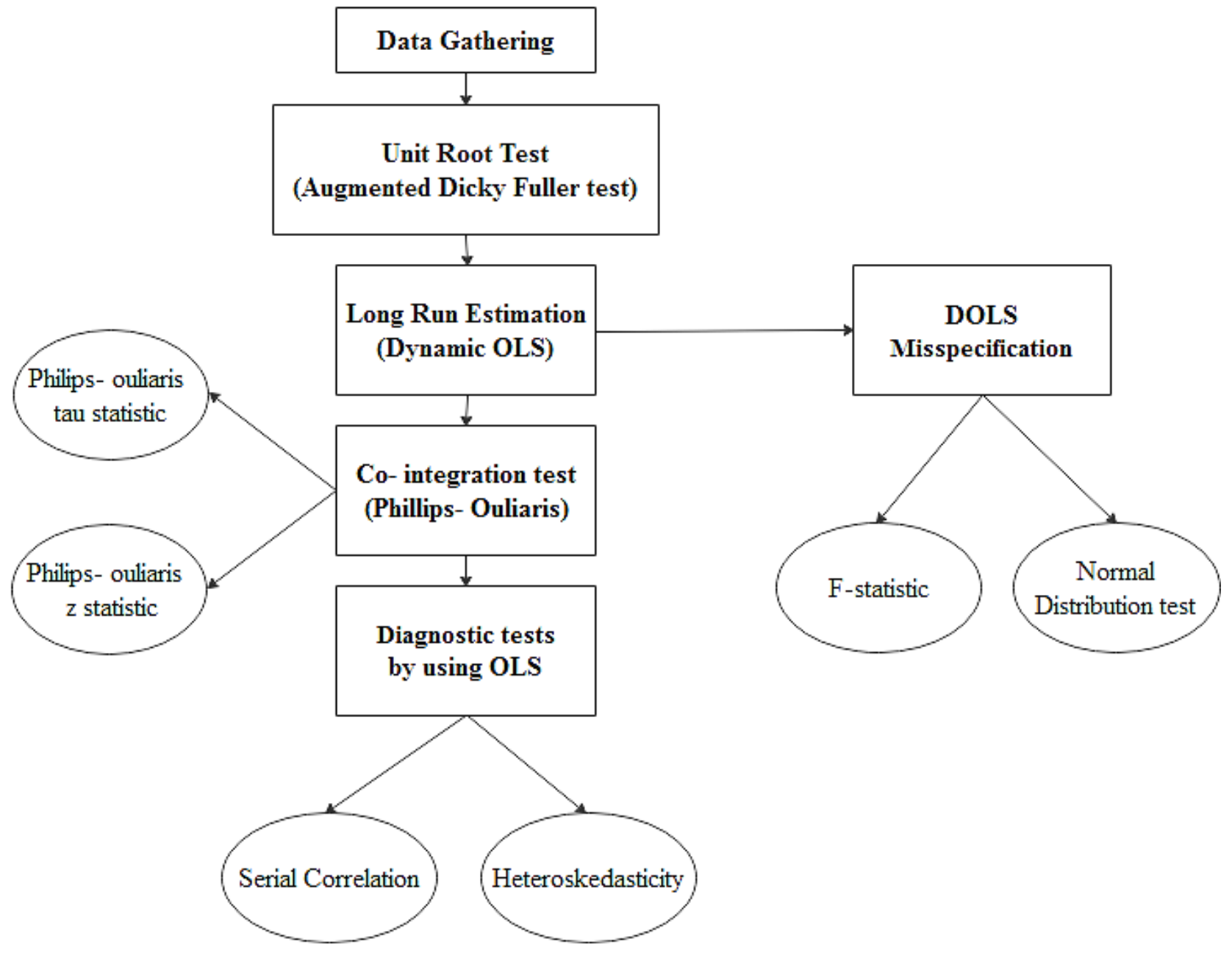

Figure 4. Flowchart of the research methodology.

\section{4- Empirical Analysis}

Diagnostic tests were carried out to use the appropriate standard model to analyze data during the study period (2000-2017). These diagnostic tests include the stationary unit root tests (Augmented Dicky Fuller test) [30], Autocorrelation test, Heteroscedasticity test, Normal distribution test, Lag Length Selection Time (LLST), and Cointegration test [31]. Whereas Dynamic Ordinary Least Square (DOLS) was used as a statistical analysis tool. 
Table 2. Results of ADF unit root test.

\begin{tabular}{cccc}
\hline Variables & Panel A: Level & Panel B: 1st difference & Results \\
\hline & Actual value & Actual value & \\
GGDP & -1.4996 & $-4.556903 * * *$ & $\mathrm{I}(1)$ \\
GINFR & -1.3797 & $-5.037771^{* * *}$ & $\mathrm{I}(1)$ \\
TR & -1.9341 & $-4.127731^{* * *}$ & $\mathrm{I}(1)$ \\
FDI & -1.8688 & $-4.794356 * * *$ & $\mathrm{I}(1)$ \\
\hline
\end{tabular}

Notes: Maximum lag order is set to two and optimal lag order $(\mathrm{k})$ is selected based on Schwarz criterion in $\mathrm{ADF}$ test; $* * *$ and $* * *$ accordingly indicate rejection of null hypothesis at $10 \%, 5 \%$ and $1 \%$ significance levels; critical values are taken from the table prepared by MacKinnonun (1996). Time period: 2000- 2017.

Since the variables showed a stationary at first difference, and to estimate a long-term equilibrium relationship between these variables, therefore DOLS method was used to estimate the long-term relationship and the results were as follows:

Table 3. Results in the long term.

\begin{tabular}{|c|c|c|c|c|}
\hline \multicolumn{5}{|c|}{ Panel A: DOLS Co integrating } \\
\hline \multicolumn{5}{|c|}{ Dependent Variable: GGDP } \\
\hline \multicolumn{5}{|c|}{ Sample adjusted: 2001S2 2017S1 } \\
\hline \multicolumn{5}{|c|}{ Included observations: 32 after adjustment } \\
\hline \multicolumn{5}{|c|}{ Cointegrating equation deterministics: $\mathrm{C}$} \\
\hline \multicolumn{5}{|c|}{ Fixed lead and lags specification $(\operatorname{Lead}=1, \mathrm{Lag}=1)$} \\
\hline Variables & Coefficient & St. error & t- statistic & Prob. \\
\hline GINFR & 0.373872 & 0.104124 & 3.590630 & 0.0019 \\
\hline TR & 0.155620 & 0.035706 & 4.358306 & 0.0003 \\
\hline FDI & 0.055826 & 0.012783 & 4.367174 & 0.0003 \\
\hline $\mathrm{C}$ & -9.683828 & 2.039638 & -4.74781 & 0.0001 \\
\hline
\end{tabular}

Specification with fixed lead and lags (Lead=1, $\operatorname{Lag}=1)$ :

GGDP $=0.373872256501 *$ GINFR $+0.1556198083 * \mathrm{TR}+0.0558255365742 *$ FDI -9.6838276233.

\begin{tabular}{c}
\hline Panel C: Residual Diagnostics and Misspecification test results for DOLS fixed lead and lag. \\
\hline$J B_{N}=0.675[0.7135], F_{\text {statistic }}=4.818[0.0012], R$-squared $=0.7526$, Adjusted $R$-squared $=0.5964$.
\end{tabular}

Notes: $\boldsymbol{J} \boldsymbol{B}_{\boldsymbol{N}}$ and $\boldsymbol{F}_{\boldsymbol{F}}$ indicate Jarque-Bera and F-statistic to test the null hypotheses of normal distribution and the significance probability of the model respectively, and; $R$-squared and adjusted $R$-squared to indicate the ability of independent variables to interpret the dependent variable change.

After estimating the model variables by DOLS, Phillips- Ouliaris test was used to estimate the Co-integration relationship during study period [32], and the result as follow:

Table 4. Co- integration test- Phillips- Ouliaris.

\begin{tabular}{ccc}
\hline & Value & Prob. \\
\hline Philips- ouliaris tau statistic & 3.508037 & 0.2046 \\
Philips- ouliaris z statistic & -16.67033 & 0.3081 \\
\hline $\begin{array}{l}\text { Probability of tau statistic }=-3.508037[0.2046], \text { and this value more than 10\%, so we reject null hypothesis and accept } \\
\text { the alternative hypothesis which indicate that there are co- integration relationship in the long run among variables during } \\
\text { study period. }\end{array}$
\end{tabular}

Dynamic OLS has limited ability to indicate the results of some diagnostic tests such as serial correlation, heteroskedasticity and stability test. So we use Ordinary Least Square (OLS) with the fixed specification (Lead= 1, $\mathrm{Lag}=1$ ). The equation has to be estimated by OLS regression with a fixed specification to become as follow:

$\mathrm{GGDP}=\mathrm{C}(1) * \mathrm{GINFR}+\mathrm{C}(2) * \mathrm{TR}+\mathrm{C}(3) * \mathrm{FDI}+\mathrm{C}(4) * \mathrm{D}(\mathrm{GINFR})+\mathrm{C}(5) * \mathrm{D}(\mathrm{GINFR}(1))+\mathrm{C}(6) * \mathrm{D}(\mathrm{GINFR}(-1))+$ $\mathrm{C}(7) * \mathrm{D}(\mathrm{TR})+\mathrm{C}(8) * \mathrm{D}(\mathrm{TR}(1))+\mathrm{C}(9) * \mathrm{D}(\mathrm{TR}(-1))+\mathrm{C}(10) * \mathrm{D}(\mathrm{FDI})+\mathrm{C}(11) * \mathrm{D}(\mathrm{FDI}(1))+\mathrm{C}(12) * \mathrm{D}(\mathrm{FDI}(-1))+\mathrm{C}(13)$.

And the OLS result has to be the same DOLS result, because we use fixed specification ( $\operatorname{Lead}=1, \mathrm{Lag}=1)$, and the result was as follow: 
Table 5. Using OLS to estimate diagnostic tests.

\begin{tabular}{|c|c|c|c|c|}
\hline \multicolumn{5}{|c|}{ Panel A: OLS (Ordinary Least square) } \\
\hline \multicolumn{5}{|c|}{ Dependent Variable: GGDP } \\
\hline \multicolumn{5}{|c|}{ Sample adjusted: 2001S2 2017S1 } \\
\hline \multicolumn{5}{|c|}{ Included observations: 32 after adjustment } \\
\hline Variables & Coefficient & St. error & t- statistic & Prob. \\
\hline GINFR & 0.373872 & 0.104124 & 3.590630 & 0.0019 \\
\hline $\mathrm{TR}$ & 0.155620 & 0.035706 & 4.358306 & 0.0003 \\
\hline FDI & 0.055826 & 0.012783 & 4.367174 & 0.0003 \\
\hline D(GINDR) & -0.11929 & 0.122238 & -0.975927 & 0.3414 \\
\hline $\mathrm{D}(\operatorname{GINFR}(1))$ & 0.451525 & 0.125468 & 3.598734 & 0.0019 \\
\hline $\mathrm{D}(\operatorname{GINFR}(-1))$ & 0.147729 & 0.113637 & 1.300011 & 0.2091 \\
\hline $\mathrm{D}(\mathrm{TR})$ & 0.176513 & 0.157299 & 1.122154 & 0.2758 \\
\hline $\mathrm{D}(\mathrm{TR}(1))$ & 0.048926 & 0.157860 & 0.309932 & 0.7600 \\
\hline $\mathrm{D}(\mathrm{TR}(-1))$ & -0.034502 & 0.150770 & -0.228841 & 0.8214 \\
\hline $\mathrm{D}(\mathrm{FDI})$ & -0.023728 & 0.012010 & -1.975630 & 0.0629 \\
\hline $\mathrm{D}(\mathrm{FDI}(1))$ & 0.028565 & 0.015092 & 1.892638 & 0.0737 \\
\hline $\mathrm{D}(\mathrm{FDI}(-1))$ & -0.013945 & 0.010326 & -1.350413 & 0.1928 \\
\hline $\mathrm{C}$ & -9.683828 & 2.115200 & -4.578209 & 0.0002 \\
\hline
\end{tabular}

Panel B: Residual Diagnostics and Misspecification test results for DOLS fixed lead and lag.

$\chi_{S C}^{2}(2)=2.40$ [0.1207], $\chi_{A R C H}^{2}(1)=1.244[0.2645], J B_{N}=0.675[0.7135], F_{\text {statistic }}=4.818$ [0.0012], $R$-squared $=0.7562$,

Adjusted R-squared $=0.5964$.

Notes: $\chi_{S C}^{2}, \chi_{A R C H}^{2}$ denote Chi-squared statistics to test the null hypotheses of no serial correlation, no autoregressive conditioned heteroscedasticity, and; $J B_{N}$ and $F_{F F}$ indicate Jarque-Bera and F-statistic to test the null hypotheses of normal distribution and the significance probability of the model respectively, and; R-squared and Adjusted $R$-squared to indicates the ability of independent variables to interpret the dependent variable change.

From the table above, the results by using OLS were consistent with the results obtained from DOLS, and the diagnostic tests showed that the model is free of various statistical problems such as serial correlation and heteroskedasticity. Also, the variables are normally distributed. And the results show that the adjusted-R square (adjR2) was $59.6 \%$, this means the independent variables combined explain $59.6 \%$ of the change in the growth of GDP (GGDP), and the results indicate that all parameters in the model are statistically acceptable at $1 \%$ significant level.

\section{5- Conclusions}

The main objective of this study was to examine the heavily affected variables with Germany World Cup hosting (represented by growth of infrastructure spending, tourism revenues and foreign direct investment) on the German economic growth (GGDP) in the period 2000- 2017, and concluded as follow:

- There is a long- term common integrative relationship between the independent variables (GINFR, TR, FDI) and the dependent variable (GGDP).

- There is a positive and statistically significant relationship between the growth of infrastructure spending (GINFR) to the growth of domestic product (GGDP), the higher the (GINFR) 1unit, the higher the (GGDP) by 0.374 unit with the stability of the impact of other factors. The large influx of visitors, fans, journalists, media professionals, and sports officials that accompanies huge events, requires the host country to prepare and develop an urban infrastructure that includes the construction and rehabilitation of airports, roads, modern means of transportation and hotels, in addition to stadiums and sports facilities. Some studies show that mega-events accelerate and contribute to the development of infrastructure for a period of up to 10 years [33]. Hosting megaevents can also be used as a tool and as a way to extract funding from central government and taxpayers, as evidenced by London Mayor Ken Livingston's interest in hosting the 2012 Olympic Games and his famous saying, "I didn't bid for the Olympics because I wanted to play sports for three weeks, of pounds from the government to develop the eastern tip" [34]. The result of the study is consistent with economic logic, as increased spending on infrastructure increases employment, faster cash circulation, and increases demand for goods and services, thus increasing Economic growth.

- There is a positive and statistically significant relationship between the tourism revenues (TR) to the growth of domestic product (GGDP), the higher the (TR) 1unit, the higher the (GGDP) by 0.155 unit with the stability of 
the impact of other factors. Mega events play an important role in making host cities attractive to tourism, not only in the year of the event but in the long term. Economists have referred to the so-called "Barcelona Model", where the hosting of the 1992 Olympic Games transformed the city into a major long-term tourist destination [35]. One of the studies showed that huge events increase the percentage of tourists in the year of the event by $8 \%$ [36], and this study showed the positive impact of tourism revenues as a result of hosting the 2006 World Cup on long-term economic growth.

- There is a positive and statistically significant relationship between the foreign direct investment (FDI) to the growth of domestic product (GGDP), the higher the (FDI) 1unit, the higher the (GGDP) by 0.055 unit with the stability of the impact of other factors. One of the reasons why countries seek to host mega-events is to create positive publicity for them and a strong indication of the extent of political and economic stability of the host country, which in turn constitutes the most important incentives and factors for attracting foreign investments [37]. The presence of a suitable investment climate in a country encourages foreign investors to transfer their investments to it, which in turn will increase economic growth. This study showed the positive impact of foreign direct investment on economic growth in Germany and highlighted the role of hosting the 2006 World Cup in stimulating foreign direct investment and thus raising economic growth.

We note that the results of this study are consistent with the results of some previous studies in terms of the positive impact of mega events on the economy. The Youndong study (2013) showed that there is a positive long-term impact of hosting the World Cup on the macroeconomic indicators of the host country. The study of Breus (2007) also showed the positive impact of the 2006 World Cup on economic growth in Germany and Munich in particular. We also find the study of Wolfe et al. (2021) and Do et al. (2021) study, which also show the positive impact of hosting mega sporting events such as the Olympics games and the FIFA World Cup on urban development in the host cities.

Depending on the results of the study, some recommendations can be identified, including:

- The World Cup is a sports economic organization, so the benefits of hosting the World Cup must be positively reflected on the state. The rapid economic return remains limited, but it is important to achieve long-term gains. The study recommends benefiting from this huge event by marketing the country globally and making it a tourism destination. Furthermore, the study recommends the importance of continuous (before and after the sport events) investment in the development of infrastructure such as roads, airports, transport means and sports stadiums.

- The study targeted Germany, which is one of the highly developed countries. It recommends targeting other developing countries that hosted the tournament such as Brazil 2010, to evaluate the difference in the experiences of developing and developed countries in hosting mega events. The study also recommends using other potential explanatory economic variables related to the hosting event, taking into consideration the descriptive and statistical aspects of the analysis, and studying the social implications of hosting the World Cup, such as optimism, birth rate and increasing sense of national identity.

\section{6- Declarations}

\section{6-1- Author Contributions}

Conceptualization, M.M.A., J.M. and A.A.; methodology, M.M.A.; software, M.M.A. and J.M.; validation, J.M. and A.A.; formal analysis, M.M.A.; investigation, M.M.A.; resources, M.M.A., J.M., and A.A.; data curation, M.M.A. and J.M.; writing — original draft preparation, M.M.A.; writing - review and editing, M.M.A.; visualization, M.M.A.; supervision, J.M. and A.A.; project administration, M.M.A., J.M., and A.A.; funding acquisition, M.M.A., J.M., and A.A. All authors have read and agreed to the published version of the manuscript.

\section{6-2- Data Availability Statement}

The data presented in this study are available in article.

\section{6-3- Funding}

The authors received no financial support for the research, authorship, and/or publication of this article.

\section{6-4- Conflicts of Interest}

The authors declare that there is no conflict of interests regarding the publication of this manuscript. In addition, the ethical issues, including plagiarism, informed consent, misconduct, data fabrication and/or falsification, double publication and/or submission, and redundancies have been completely observed by the authors. 


\section{7- References}

[1] Greene, Solomon. "Staged Cities: Mega-Events, Slum Clearance, and Global Capita." Yale Human Rights and Development Journal 6, no. 1 (2003): 161-181.

[2] Hall, Stefan, Engagement Lead, and World Economic Forum. "Does Hosting a World Cup Make Economic Sense?" Project and Engagment Lead, (2018), 1-7. Available online: https://www.weforum.org/agenda/2018/06/world-cup-football-smartinvestment-russia-host/ (accessed on August 2021).

[3] Global Banking and Finance Review. "The Economics of the FIFA World Cup 2018." Available online: https://www.globalbankingandfinance.com/the-economics-of-the-fifa-world-cup-2018/ (accessed on March 2021).

[4] für, Gesellschaft "Mega-events as an Engine for Sustainable Development." Agency for Market-Orientated Concepts. H. Reuffurth GmbH, Mühlheim am Main (2013).

[5] Hermann, U, Willem JL Coetzee, Liezel du Plessis, and Sue Geldenhuys. "Economic impacts of the FIFA World Cup." Conference: 2012 Leisure and Recreation Association of South Africa Congress, At Durban, South Africa (2012): 282 - 295.

[6] Liu, Yundong. “Assessing the Long-Term Economic Impacts of the World Cup as Mega-Sport Event.” PIT Journal 4 (2013). Available online: https://pitjournal.unc.edu/article/assessing-long-term-economic-impacts-world-cup-mega-sport-event (accessed on August 2021).

[7] Li, Shina. "Large Sporting Events and Economic Growth: Evidence from Economic Consequences of Event Infrastructure and Venues.” Event Management 17, no. 4 (2013): 425-38. doi:10.3727/152599513X13769392444747.

[8] Lee, Choong Ki, James W. Mjelde, and Younghyun J. Kwon. "Estimating the Economic Impact of a Mega-Event on Host and Neighbouring Regions.” Leisure Studies 36, no. 1 (2017): 138-52. doi:10.1080/02614367.2015.1040828.

[9] Amponsah, Christian Tabi, Gouher Ahmed, Manoj Kumar, and Samuel Adams. "The Business Effects of Mega-Sporting Events on Host Cities: An Empirical View." Problems and Perspectives in Management 16, no. 3 (2018): 324-36. doi:10.21511/ppm.16(3).2018.26.

[10] Sumarsono, Dicky, Putut Suharso, and Sarbini. "The Effects of Tourism Event on Economic Growth in Surakarta." Proceedings of the 3rd International Conference on Social Sciences, Laws, Arts and Humanities (2018): 205-210. doi:10.5220/0010005102050210.

[11] Wan, Shui Ki, and Haiyan Song. "Economic Impact Assessment of Mega-Events in the United Kingdom and Brazil." Journal of Hospitality and Tourism Research 43, no. 7 (2019): 1044-67. doi:10.1177/1096348019851838.

[12] Oshimi, Daichi. "Social Impact of Mega-Sporting Events.” Japanese Journal of Sport Management 12, no. 1 (2020): 3-16. doi:10.5225/jjsm.2020-001.

[13] Wolfe, Sven Daniel, David Gogishvili, Jean Loup Chappelet, and Martin Müller. "The Urban and Economic Impacts of MegaEvents: Mechanisms of Change in Global Games.” In Sport in Society, 1-9, 2021. doi:10.1080/17430437.2021.1903438.

[14] Do, Jinwoo, Sangho Ahn, and Juyoung Kang. "Urbanization Effect of Mega Sporting Events Using Sentinel-2 Satellite Images: The Case of the Pyeongchang Olympics." Sustainable Cities and Society 74 (2021): 103158. doi:10.1016/j.scs.2021.103158.

[15] Ahlert, Gerd. "Hosting the FIFA World CupTM Germany 2006: Macroeconomic and Regional Economic Impacts.” Journal of Convention and Event Tourism 8, no. 2 (2007): 57-78. doi:10.1300/J452v08n02_04.

[16] Raithel, Thomas. "The German Nation and the 2006 FIFA World Cup.” In The FIFA World Cup 1930-2010, (2014): 353371. doi:10.5771/9783835326064-353.

[17] Gntb. "The 2006 FIFA World Cup - and Its Effect on the Image and Economy of Germany." Germany Tourism, 2006. Available online: https://www.germany.travel/media/en/pdf/dzt_marktforschung/Fazit_der_FIFA_WM_2006_PDF.pdf (accessed on July 2021).

[18] Allmers, Swantje, and Wolfgang Maennig. "Economic Impacts of the FIFA Soccer World Cups in France 1998, Germany 2006, and Outlook for South Africa 2010.” Eastern Economic Journal 35, no. 4 (2009): 500-519. doi:10.1057/eej.2009.30.

[19] Coates, Dennis, and Victor A. Matheson. "Mega-Events and Housing Costs: Raising the Rent While Raising the Roof?" Annals of Regional Science 46, no. 1 (2011): 119-37. doi:10.1007/s00168-009-0340-5.

[20] Al-Emadi, A., K. Kaplanidou, A. Diop, M. Sagas, K. T. Le, and S. Al-Ali Mustafa. "2022 Qatar World Cup: Impact Perceptions among Qatar Residents.” Journal of Travel Research 56, no. 5 (June 20, 2016): 678-694. doi:10.1177/0047287516652502.

[21] Preuss, Holger. "FIFA World Cup 2006 and Its Legacy on Tourism.” In Trends and Issues in Global Tourism 2007, 83-102, 2007. doi:10.1007/978-3-540-70905-3_8. 
[22] Nollen, Patricio. Claims of Overspending From Government, Is The Soccer Gompetion Harming. Brazil: International Business Time. Available online: http://goo.gl/BuBjdz (accessed on July 2021).

[23] Pillay, Udesh, and Orli Bass. "Mega-Events as a Response to Poverty Reduction: The 2010 FIFA World Cup and Its Urban Development Implications.” Urban Forum 19, no. 3 (2008): 329-46. doi:10.1007/s12132-008-9034-9.

[24] Muhamad, Sudfah. "Brazil and the Organization of the World Cup in the Balance of the Economy." Al Shorouk Newspaper 1164 (2014): $28-30$.

[25] Muhamad, Hamed. "Olympics brings China economic and tourism recovery." Elaph (2008). Available online: http://goo.gl/MhxA3n (accessed on August 2021).

[26] "National Accounts Data". World Bank (2000-2018). Available Online: https://data.worldbank.org/country (accessed on 17 April 2020).

[27] UNCTAD, "World Investment Report, FDI from Developing and Transition Economics: Implications for Development". United Nations Conference on Trade and Development (UNCTAD) World Investment Report (WIR) (April 2018). Available Online: https://unctad.org/en/PublicationsLibrary/wir2018_en.pdf (accessed on 21 May 2020).

[28] Duignan, Michael B. “Utilising Field Theory to Examine Mega-Event Led Development.” Event Management, 2021. doi:10.3727/152599520x15894679115583.

[29] Maeshiro, Asatoshi. "OLS and a Dynamic Model with Autocorrelated Disturbances." Atlantic Economic Journal 15, no. 3 (1987): 78. doi:10.1007/BF02316892.

[30] Harris, R. I.D. "Testing for Unit Roots Using the Augmented Dickey-Fuller Test. Some Issues Relating to the Size, Power and the Lag Structure of the Test.” Economics Letters 38, no. 4 (1992): 381-86. doi:10.1016/0165-1765(92)90022-Q.

[31] Gujarati, Damodar. "Econometrics” (2015). doi:10.1007/978-1-137-37502-5.

[32] Haug, Alfred A. "Critical Values for the Ž $\alpha$-Phillips-Ouliaris Test for Cointegration*." Oxford Bulletin of Economics and Statistics 54, no. 3 (1992): 473-80. doi:10.1111/j.1468-0084.1992.tb00014.x.

[33] Preuss, Holger. "Calculating the Regional Economic Impact of the Olympic Games.” European Sport Management Quarterly 4, no. 4 (December 2004): 234-253. doi:10.1080/16184740408737479.

[34] Daily Telegraph (UK). "Mayor tricked Govt". into 2012 Olympics bid', 25 April 2008. Available Online: https://www.telegraph.co.uk/sport/olympics/2298374/Mayor-tricked-Govt.-into-2012-Olympics-bid.html (accessed on 21 May 2020).

[35] Monclús, Francisco Javier. “The Barcelona Model: An Original Formula? From 'reconstruction' to Strategic Urban Projects (1979-2004).” Planning Perspectives 18, no. 4 (2003): 399-421. doi:10.1080/0266543032000117514.

[36] Fourie, Johan, and María Santana-Gallego. “The Impact of Mega-Sport Events on Tourist Arrivals.” Tourism Management 32, no. 6 (2011): 1364-70. doi:10.1016/j.tourman.2011.01.011.

[37] Jakobsen, Jo, Harry Arne Solberg, Thomas Halvorsen, and Tor Georg Jakobsen. "Fool's Gold: Major Sport Events and Foreign Direct Investment.” International Journal of Sport Policy 5, no. 3 (2013): $363-80$. doi:10.1080/19406940.2012.717099. 